\title{
Pewarisan Sifat Densitas Stomata dan Laju Kehilangan Air Daun (rate leaf water loss RWL) pada Kacang Tanah (Arachis hypogaea L.)
}

\author{
Adisyahputra $^{\left.1^{*}\right)}$, Sudarsono ${ }^{2)}$ dan Kukuh Setiawan ${ }^{3)}$ \\ ${ }^{1)}$ Jurusan Biologi, Fakultas Matematika dan Ilmu Pengetahuan Alam, Universitas Negeri Jakarta, Jakarta 13220 \\ 2)Jurusan Agronomi, Fakultas Pertanian, Institut Pertanian Bogor, Bogor 16680 \\ ${ }^{3)}$ Jurusan Agronomi, Fakultas Pertanian, Universitas Lampung, Bandar Lampung 35145
}

Diterima 09-01-2010 Disetujui 14-04-2011

\begin{abstract}
The aim of this research is to analyze and examine the inheritance of stomatal density trait and RWL as a variable in drought tolerance of peanut. The experiment was conducted by using cv. Kelinci that is sensitive genotype as female parent and US 605 which is tolerant genotype as male parent, including population off spring from hybrid cv. Kelinci (P1) with US 605 (P2). Stomatal density was determined by making leaf imprint and by observing leaf imprint under microscope. Relative water loss was determined by dipping peanut leaf in PEG $40 \%$ for 48 hours. Result of the analysis showed that stomatal density and RWL were not only controlled by qualitative characters of major gene, but also controlled by quantitative character of minor gene by polygenic with the complex gene action. Both characters seem to influence more as genetic factor and have high level fixation additive varians which can give the opportunity to obtain the tolerant off spring.
\end{abstract}

Keywords: drought resistance, Inheritance, rate leaf water loss, stomatal density

\section{PENDAHULUAN}

Cekaman kekeringan merupakan faktor lingkungan yang membatasi pertumbuhan dan daya hasil (Tawfik 2008). Kekeringan, disebabkan oleh temperatur dan radiasi matahari yang tinggi, merupakan kondisi lingkungan yang krusial bagi keberlangsungan dan produktivitas tanaman (Ennajeh et al. 2010). Kondisi kekeringan secara signifikan menurunkan fotosintesis yang berkonsekuensi penurunan pada semua metabolisme dan energi (Xiang et al. 2006). Pada kondisi ini, pertukaran gas di daun akan menurun, dan akan menyebabkan rendahnya akumulasi biomassa dan hasil panen (Kholova et al. 2010). Pada kacang tanah, rendahnya panen terutama terhadap hasil polong dan parameter pertumbuhan lainnya (Pimratch et al. 2008; Songsri et al. 2008; Nigam et al. 2005). Kehilangan panen tersebut diperkirakan mencapai 56-85\%, tergantung pada tahap pertumbuhan mana terjadinya ekpos kekeringan tersebut, besarnya intensitas dan lamanya kekeringan (Painawadee et al. 2009).

Indikator adanya cekaman kekeringan pada tanaman adalah gejala layu pada daun (terjadinya dehidrasi pada daun). Dehidrasi daun dapat diminimalkan melalui penurunan evapotranspirasi atau melalui peningkatan absorpsi air pada tanah kering (Carmo-Silva et al. 2009).
Pada kondisi kekeringan yang paling urgen bagi tanaman adalah peningkatan pengambilan air, yang biasanya tersedia pada posisi yang lebih dalam (Xiang et al. 2006). Proses penurunan kehilangan air juga dapat dilakukan dengan penutupan stomata, penggulungan daun dan penurunan potensial air daun. Penurunan potensial air daun mungkin dapat dilakukan dengan peningkatan perubahan tekanan turgor, yang sangat tergantung pada elastisitas dinding sel, atau perubahan potensial osmotik, yang sangat tergantung pada konsentrasi larutan dalam sel (Chaves et al. 2003). Kehilangan air daun juga dapat dicapai dengan memperkecil luas permukaan daun dan mereduksi konduktansi stomata (Rauf \& Sadaqat 2008).

Pengaturan stomata memegang peran utama dalam pengendalian kehilangan air. Konduktansi stomata yang rendah berhubungan dengan densitas stomata, yang kemungkinan berperan dalam pola konservasi penggunaan air (Kholova et al. 2010). Stomata mengatur status air tanaman melalui regulasi banyaknya ekstraksi air dari tanah oleh tanaman dengan pengontrolan laju kehilangan air ke atmosfer (Aspinwall et al. 2011). Kecepatan penutupan stomata, sebagai respons stomata terhadap perubahan defisit tekanan uap, sangat ditentukan oleh sensitivitas stomata (Domec et al. 2009). Defisit tekanan uap antara daun

*Telp: +6281281487880

Email: adisyahputra_bio@yahoo.com 
dan udara menjadi driving force transpirasi. Transpirasi akan meningkat seiring dengan peningkatan defisit tekanan uap dari udara kering (Aspinwall et al. 2011).

Konduktansi stomata yang rendah merupakan indikator tipe tanaman toleran kekeringan. Tingginya resistensi mengindikasikan penurunan kehilangan air, yang penting untuk menjaga status air. Resistensi transpirasi membantu potensial air tanaman yang berperan dalam menjaga turgiditas (Solangi et al. 2010).

Untuk meminimalkan laju kehilangan air, selain faktor stomata kemampuan jaringan daun dalam menahan lepasnya molekul air merupakan faktor penting lainnya. Kemampuan daun menahan air yang ditunjukkan oleh laju kehilangan air daun Rate leaf Water Loss (RWL) dapat digunakan sebagai indikator toleransi kekeringan (Yang et al. 1991). Pada wheat, RWL dapat digunakan sebagai indikator yang sederhana tapi handal untuk toleransi kekeringan.

Untuk mendukung pengembangan genotipe kacang tanah yang toleran cekaman kekeringan evaluasi terhadap variabilitas genetik yang terkait dengan toleransi kekeringan perlu diperluas. Penggunaan peubah hasil polong ternyata tidak cukup mendukung secara signifikan. Alternatif strategi menggunakan parameter fisiologi berupa densitas stomata dan RWL perlu ditelaah lebih lanjut. Peubah tersebut dipilih sebagai karakter marka karena dari percobaan sebelumnya telah dibuktikan memiliki kehandalan yang tinggi sebagai penapis tanaman kacang tanah yang toleran.

\section{BAHANDANMETODE}

Populasi kacang tanah yang digunakan. Kacang tanah cv. Kelinci (tetua $\mathrm{P}_{1}$ yang peka, sebagai tetua betina), kacang tanah US-605 (tetua $\mathrm{P}_{2}$ yang toleran, sebagai tetua jantan), $\mathrm{F}_{1}, \mathrm{~F}_{1} \mathrm{R}, \mathrm{BC}_{1} \mathrm{P}_{1}, \mathrm{BC}_{1} \mathrm{P}_{2}$, dan populasi bersegregasi tanaman $\mathrm{F}_{2}$ zuriat dari tanaman $F_{1}$ hasil persilangan antara tetua $P_{1}$ dan $\mathrm{P}_{2}$. Pengujian dilakukan pada pot plastik berukuran tinggi $20 \mathrm{~cm}$ dan diameter $30 \mathrm{~cm}$ berisi 6 liter media tanam campuran tanah:pasir:pupuk kandang (4:1:1) yang telah disterilkan dengan pemanasan. Pemupukan dengan kapur pertanian $10 \mathrm{~g}$, urea $4 \mathrm{~g}, \mathrm{KCl} 4 \mathrm{~g}$ dan TSP $2 \mathrm{~g}$.

10 tanaman dari $\mathrm{P}_{1}, \mathrm{P}_{2}, \mathrm{~F}_{1}, \mathrm{~F}_{1} \mathrm{R}, \mathrm{BC}_{1} \mathrm{P}_{1}, \mathrm{BC}_{1} \mathrm{P}_{2}$, dan $\mathrm{F}_{2}$ dipelihara dalam kondisi optimum, yaitu disiram air hingga kapasitas lapang dari awal tanam hingga panen. 10 tanaman $\mathrm{P}_{1}, 10$ tanaman $\mathrm{P}_{2}, 10$ tanaman $\mathrm{F}_{1}, 10$ tanaman $\mathrm{F}_{1} \mathrm{R}, 20$ tanaman $\mathrm{BC}_{1} \mathrm{P}_{1}, 20$ tanaman $\mathrm{BC}_{1} \mathrm{P}_{2}$, dan 200 tanaman $\mathrm{F}_{2}$ diberi perlakuan cekaman kekeringan dari 12 hst (hari sesudah tanam) hingga panen. Perlakuan cekaman dilakukan dengan cara, tanaman baru disiram hingga kapasitas lapang ketika sudah menunjukkan gejala layu $75 \%$ pada tunas pucuk.
Penghitungan densitas stomata. Penghitungan densitas stomata dengan teknik imprint, yaitu mencetak stomata daun menggunakan kuteks (cat kuku). Imprint dilakukan pada daun tetrafoliat kelima dari pucuk untuk setiap cabang tanaman kacang tanah yang berumur 75 hst. Imprint dilakukan dengan mengoleskan kuteks trasparan dari arah tulang daun menuju tepi daun dengan lebar sekitar 0,5 $\mathrm{cm}$. Penghitungan stomata dengan menggunakan mikroskop.

Pengukuran RWL daun dengan metode DLA. Pengukuran Rate leaf Water Loss (RWL) dilakukan dengan menggunakan metode DLA. Pengujian RWL dilakukan pada daun tetrafoliat kelima dari pucuk untuk setiap cabang tanaman kacang tanah yang berumur 75 hst. Dari setiap tetrafoliat dipilih satu anak daun untuk penghitungan RWL dan dari setiap tanaman diambil empat tetrafoliat sebagai contoh. Daun untuk penghitungan densitas stomata dan RWL berasal dari satu tetrafoliat yang sama. Contoh anak daun direndam dalam $30 \mathrm{ml}$ larutan penyangga hepes (hepes 2,5 mM; $\mathrm{CaCl}_{2} 1,5 \mathrm{mM}$ dan $\mathrm{K}_{2} \mathrm{SO}_{4} 1 \mathrm{mM}$ ) selama 6 jam sebagai prakondisi. Setelah prakondisi contoh daun ditimbang bobot awalnya (BA). Selanjutnya contoh daun direndam dalam larutan penyangga hepes yang sama dengan penambahan PEG 40\% selama 48 jam. Inkubasi dilakukan di bawah peyinaran 700 lux pada ruangan dengan suhu ruang $22^{\circ} \mathrm{C}$. Selesai perendaman daun ditimbang kembali bobotnya (BS). (RWL) dihitung dengan rumus:

RWL : [(BA-BS)/BA] x $100 \%$.

RWL : rate leaf water loss

BA : bobot (g) awal anak daun setelah pra-kondisi dan sebelum perendam dalam larutan PEG (40\% 48 jam)

BS : bobot $(\mathrm{g})$ anak daun setelah perlakuan perendaman dalam larutan PEG (40jam, 48 jam)

Analisis data. Pada tahap awal dilakukan uji pengaruh tetua betina berdasarkan uji t terhadap rata-rata F1 dan F1R untuk kedua peubah. Derajat dominansi setiap peubah dihitung untuk menduga aksi gen yang mengendalikan karakter tersebut dibawah kondisi tercekaman kekeringan. Derajat dominansi dihitung berdasarkan rumus pendugaan potensi rasio (hp) yang dikemukakan oleh Petr dan Frey (1966).

Jumlah gen pengendali densitas stomata dan RWL diestimasi berdasarkan sebaran frekuensi data masing-masing peubah pada populasi $\mathrm{F}_{2}$. Untuk menduga jumlah gen yang bersegregasi dilakukan dengan pendekatan Lande (1981), atau Das dan Griffey (1994). Jika sebaran frekuensi data $\mathrm{F}_{2}$ bersifat diskret dan tidak mengikuti sebaran normal, 
kemungkinan ada peran gen mayor dan untuk mengetahui jumlah gen mayor yang terlibat dalam aksi gen maka sebaran frekuensi tersebut dibandingkan terhadap nisbah Mendel atau nisbah fenotipik tertentu dengan uji Chi-Kuadrat (Crowder 1993). Bila membentuk sebaran terusan dengan dua puncak atau lebih, maka karakter tersebut dikendalikan oleh beberapa gen mayor dan minor sekaligus (Fehr 1987).

Uji skala gabungan (joint scaling test) (Mather \& Jinks 1971), dan uji kebaikan suai $\mathrm{c}^{2}$ terboboti (weighted $\mathrm{c}^{2}$ ) (Simon 1994), dilakukan dalam menentukan model genetik yang paling sesuai untuk menggambarkan hubungan rata-rata antar generasi untuk kedua karakter. Nilai duga heritabilitas arti luas $\left(\mathrm{h}_{\mathrm{bs}}^{2}\right)$ dan arti sempit $\left(\mathrm{h}^{2}{ }_{\mathrm{ns}}\right)$ dihitung dengan rumus.

\section{HASIL DAN PEMBAHASAN}

Menghadapi lingkungan yang tercekam kekeringan, adaptasi yang paling menguntungkan adalah jika tanaman mampu menahan laju transpirasi. Untuk mencegah kehilangan air akibat transpirasi, tanaman harus mampu mengembangkan ketahanan stomata dan kemampuan daun menahan air (Tawfik 2008) dalam mengimbangi penurunan potensial air di udara. Cara ini akan tetap menjamin kapasitas sistem hidraulik pada jaringan (Aspinwall et al. 2011), daun

Tabel 1 Rata-rata, galat baku, dan derajat dominansi densitas stomata (DS) dan (RWL) daun kacang tanah generasi hasil persilangan Kelinci x US-605 pada kondisi tercekam kekeringan

\begin{tabular}{lcc}
\hline Generasi & Densitas stomata (DS) & Laju kehilangan air (RWL) \\
\hline P1 & $169,72 \pm 4,06$ & $41,59 \pm 2,37$ \\
P2 & $146,22 \pm 2,29$ & $29,94 \pm 1,36$ \\
F1 & $157,43 \pm 1,58$ & $22,05 \pm 1,50$ \\
BC1P1 & $166,30 \pm 3,90$ & $38,98 \pm 2,11$ \\
BC1P2 & $153,29 \pm 2,64$ & $36,13 \pm 1,28$ \\
F2 & $154,33 \pm 1,22$ & $32,04 \pm 0,56$ \\
hp & $-0,0462$ & $-2,3538$ \\
\hline
\end{tabular}

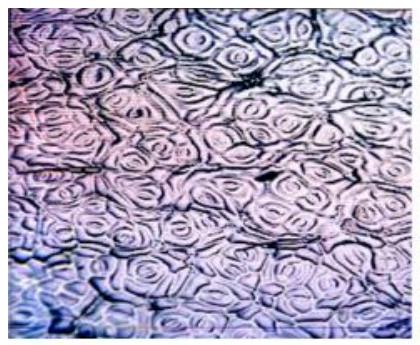

P1 Kelinci

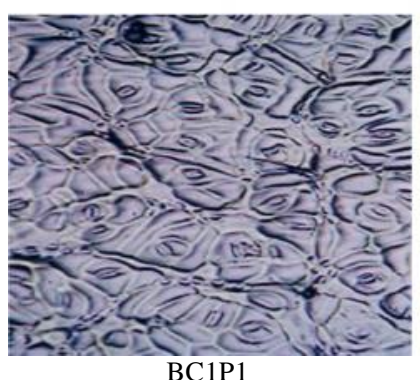

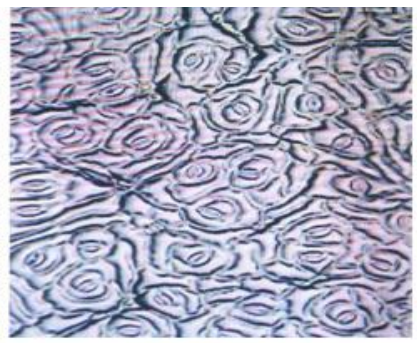

P2 US-605

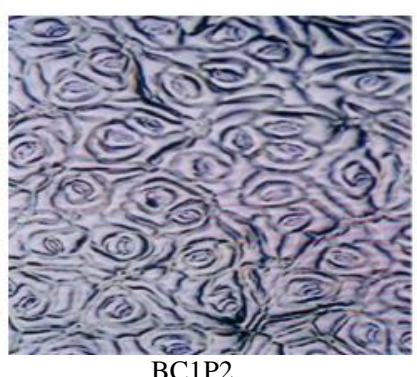

diantaranya. Melalui mekanisme tersebut, selain dapat membatasi banyaknya kehilangan air melalui transpirasi, tanaman juga tetap dapat menjaga luas daun yang bertanggung-jawab dalam fotosintesis.

Dari hasil pengamatan telah diketahui rata-rata densitas stomata dan RWL masing-masing generasi (Tabel 1). Dari data tersebut diketahui bahwa ada hubungan yang erat antara besaran densitas stomata dan RWL dengan ketahanan terhadap cekaman kekeringan. Tetua P2 (US-605) yang bersifat toleran memiliki rata-rata densitas stomata dan RWL yang kecil dibandingkan rataan yang lebih besar pada tetua P1 (cv. Kelinci) yang peka (Tabel 2). Sedangkan ratarata amatan kedua peubah pada generasi $F 1$ dan $\mathrm{F}_{1} \mathrm{R}$ tidak menunjukkan perbedaan yang nyata. Dari harga heritabilitas yang diperoleh, diketahui bahwa karakter densitas stomata dan RWL tampak lebih dipengaruhi oleh faktor genetik dibandingkan faktor lingkungan dan karakter tersebut dapat secara mudah diwariskan sehingga memperbesar kemungkinan memunculkan kedua karakter toleran terhadap cekaman kekeringan tersebut pada generasi hasil persilangan.

Densitas stomata. Diketahui bahwa sebaran frekuensi densitas stomata pada kedua tetua tidak tumpang tindih

Tabel 2 Perbandingan rata-rata densitas stomata (DS) dan (RWL) daun kacang tanah generasi F1 dan F1R hasil persilangan Kelinci x US-605 pada kondisi tercekam kekeringan

\begin{tabular}{lcc}
\hline & \multicolumn{2}{c}{ Peubah } \\
\cline { 2 - 3 } Parameter dan Generasi & $\begin{array}{c}\text { Densitas stomata } \\
(\mathrm{DS})\end{array}$ & $\begin{array}{c}\text { Laju kehilangan } \\
\text { air } \\
(\mathrm{RWL})\end{array}$ \\
\hline F1 (P1xP2 & $157,43 \pm 1,58$ & $22,05 \pm 1,50$ \\
F1R (P2xP1) & $156,83 \pm 2,67$ & $22,45 \pm 1,00$ \\
t hitung F1 vs F1R & $2,160 \mathrm{~ns}$ & $2,120 \mathrm{~ns}$ \\
t hitung P1 vs P2 & $6,287 * *$ & $3,482 * *$ \\
\hline
\end{tabular}

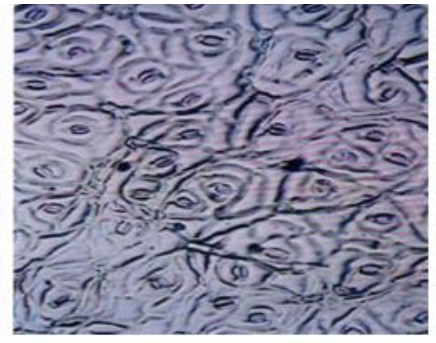

F1 (P1 x P2)

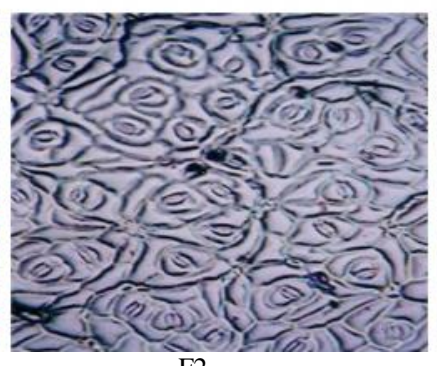

F2

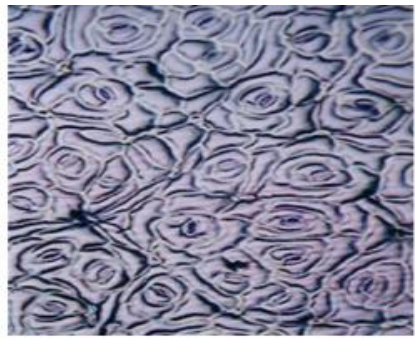

F1R (P2 x P1)

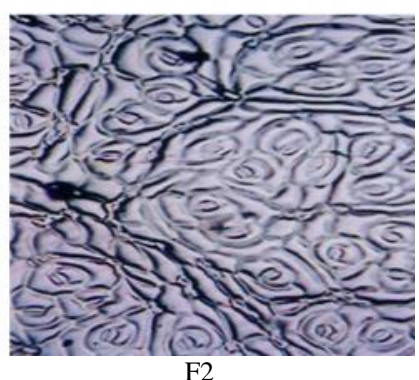

Gambar 1 Densitas stomata daun pada berbagai generasi kacang tanah hasil persilangan kelinci x US-605 pada kondisi tercekam kekeringan 
dan terdapat perbedaan yang sangat nyata (uji t pada Tabel 2 dan deskripsi data pada Gambar 1). Tetua peka cenderung memiliki densitas stomata yang jauh lebih banyak dibandingkan tetua toleran. Berdasarkan nilai derajat dominansi yang diperoleh sebesar -0,0462 adanya perbedaan tersebut disebabkan oleh pengaruh resesif dengan aksi gen tidak penuh (Tabel 1).

Sebaran dan rata-rata F1 cenderung berada di antara besaran kedua tetua. Sebaran dan rata-rata BC1P1 cenderung mengarah ke tetua peka (cv. Kelinci) serta sebaran dan rata-rata $\mathrm{BC} 1 \mathrm{P} 2$ cenderung mengikuti pola tetua toleran (US-605) (Tabel 3). Uji normalitas Shapiro-Wilk terhadap sebaran data densitas stomata pada generasi F2 diketahui bahwa data memiliki sebaran tidak normal (Tabel 4 dan Gambar 1). Sebaran data tersebut menunjukkan bahwa ada peran gen mayor dalam mengendalikan karakter densitas stomata. Oleh karena itu penelaahan karakter densitas stomata dilakukan dengan pendekatan genetika Mendel.

Tabel 3 Sebaran frekuensi densitas stomata daun populasi kacang tanah hasil persilangan cv. Kelinci x US-605

\begin{tabular}{lccc}
\hline & $\mathrm{n}$ & $\mathrm{X}$ & $\sigma^{2}$ \\
\hline P1 & 10 & 169,72 & 168,9 \\
P2 & 10 & 146,22 & 51,21 \\
F1 & 20 & 157,43 & 26,36 \\
BC1P1 & 18 & 166,3 & 275,04 \\
BC1P2 & 19 & 153,29 & 132,29 \\
F2 & 194 & 154,33 & 289,6 \\
\hline
\end{tabular}

Tabel 4 Shapiro-Wilk test terhadap sebaran data populasi F2 untuk peubah densitas stomata dan laju kehilangan air daun (RWL) populasi kacang tanah hasil persilangan cv. Kelinci x US605 pada kondisi tercekam kekeringan

\begin{tabular}{lccc}
\hline \multicolumn{1}{c}{ Karakter } & Statistik & df & signifikansi \\
\hline Densitas Stomata & 0,976 & 194 & $0,002 \mathrm{~ns}$ \\
RWL & 0,96 & 193 & $0,000 \mathrm{~ns}$ \\
\hline
\end{tabular}

Berdasarkan pengelompokkan densitas stomata ke dalam dua kelas ada 7 kelas perbandingan yang memiliki nilai $\mathrm{x}^{2}$ hitung lebih kecil dari $\mathrm{x}^{2}$ tabel (Tabel 5). Pada pengelompokkan tiga kelas ada 3 kelas perbandingan yang memiliki nilai $\mathrm{x}^{2}$ hitung lebih kecil dari $\mathrm{x}^{2}$ tabel. Pada pengelompokkan empat kelas tidak ada kelas perbandingan yang memiliki nilai $\mathrm{x}^{2}$ hitung lebih kecil dari $\mathrm{x}^{2}$ tabel. Dari semua hasil uji tersebut nisbah fenotipik 138 toleran dan 55 peka yang paling sesuai (yang memiliki nilai $\mathrm{x}^{2}$ hitung paling kecil) dengan nisbah harapan 135,7 toleran dan 57,3 peka adalah nisbah 45:19 $\left(x^{2}=0,1603\right)$. Dengan demikian densitas stomata dikendalikan oleh 3 pasang gen interaksi epistasis.

Meskipun dalam pengujian sebaran data densitas stomata tidak normal, tapi jelas terlihat bahwa sebaran data tersebut menunjukkan suatu sebaran terusan. Fakta ini juga memberikan petunjuk bahwa densitas stomata juga dikendalikan oleh gen-gen minor. Oleh karena itu untuk mendapatkan parameter genetik dugaan dilakukan analisis rata-rata generasi dengan Uji Skala Gabungan. Berdasarkan Uji Kebaikan Suai (goodness of fit test) diketahui bahwa model genetik densitas stomata mengikuti model $\mathrm{m}[\mathrm{d}][\mathrm{h}][\mathrm{i}][\mathrm{l}]$. Dengan demikian densitas stomata dikendalikan tidak saja oleh gen aditif dan dominan tetapi juga oleh pengaruh interaksi aditif $\mathrm{x}$ aditif dan pengaruh interaksi dominan x dominan (Tabel 6).

Pada model genetik yang paling sesuai berdasarkan uji skala gabungan, komponen pengaruh rata-rata $\mathrm{m}$ dan pengaruh aditif [d] memberikan sumbangan yang sangat nyata terhadap model (Tabel 7). Sedangkan komponen pengaruh dominan $[\mathrm{h}]$, pengaruh interaksi aditif $\mathrm{x}$ aditif [I],

Tabel 5 Uji khi-kuadrat $\left(\mathrm{X}^{2}\right)$ nisbah densitas stomata dan laju kehilangan air daun (RWL) kacang tanah populasi F2 hasil persilangan kacang tanah cv. Kelinci dan US-605

\begin{tabular}{|c|c|c|c|c|}
\hline Peubah & $\begin{array}{c}\text { Pengamatan } \\
\text { T:MT:P }\end{array}$ & $\begin{array}{l}\text { Harapan } \\
\text { T:MT:P }\end{array}$ & Nisbah & $\mathrm{X}^{2}$ hit \\
\hline \multirow{10}{*}{$\begin{array}{c}\text { Densitas } \\
\text { stomata }\end{array}$} & $138: 55$ & $144,75: 48,25$ & $3: 1$ & 1,1727 \\
\hline & $51: 142$ & $48,25: 144,75$ & $1: 3$ & 0,1779 \\
\hline & $163: 30$ & $156,81: 38,19$ & $13: 3$ & 1,4421 \\
\hline & 103:90 & $111,58: 81,42$ & $37: 27$ & 1,5401 \\
\hline & $119: 74$ & $111,58: 81,42$ & $37: 27$ & 1,2002 \\
\hline & 138:55 & $135,7: 57,3$ & $45: 19$ & 0,1603 \\
\hline & $163: 30$ & $165,86: 27,14$ & $55: 9$ & 0,2731 \\
\hline & $51: 87: 55$ & $48,25: 96,5: 48,25$ & $1: 2: 1$ & 1,9508 \\
\hline & $103: 35: 35$ & $108,56: 36,19: 48,25$ & $9: 3: 4$ & 1,2268 \\
\hline & 119:44:30 & $120,63: 36,19: 36,19$ & $10: 3: 3$ & 2,7510 \\
\hline Laju & $143: 39$ & $144,75: 48,25$ & $3: 1$ & 2,0052 \\
\hline kehilangan & $39: 143$ & $48,25: 144,75$ & $3: 1$ & 2,0052 \\
\hline air daun & $143: 39$ & $156,81: 36,19$ & $13: 3$ & 1,4541 \\
\hline \multirow[t]{8}{*}{ (RWL) } & 101:81 & $108,56: 84,44$ & 9:7 & 0,7824 \\
\hline & $167: 15$ & $180,94: 12,06$ & $15: 1$ & 1,6446 \\
\hline & 101:81 & $111,58: 81,42$ & $37: 27$ & 1,1103 \\
\hline & $122: 60$ & $135,70: 57,30$ & $45: 19$ & 1,5713 \\
\hline & 39:104:39 & $45,5: 91: 45,5$ & $1: 2: 1$ & 3,8709 \\
\hline & $57: 86: 39$ & $45,5: 91: 45,5$ & $1: 2: 1$ & 4,0687 \\
\hline & $101: 66: 15$ & $102,38: 68,25: 11,38$ & $9: 6: 1$ & 1,0037 \\
\hline & $101: 42: 39$ & $113,75: 34,13: 34,13$ & $9: 6: 1$ & 3,6982 \\
\hline
\end{tabular}

$\mathrm{X}^{2} 5 \%$ db $1=3,84 ; \mathrm{X}^{2} 5 \%$ db $2=5,99 ; \mathrm{X}^{2} 5 \%$ db $3=7,81$

$\mathrm{T}=$ toleran; $\mathrm{MT}=$ medium toleran; $\mathrm{P}=$ peka 
dan pengaruh interaksi dominan $\mathrm{x}$ dominan tidak memberikan sumbangan yang nyata terhadap model. Harga derajad dominansi hp yang lebih kecil dari satu juga menunjukkan bahwa gen-gen dominan kurang berpengaruh terhadap densitas stomata (Tabel 1). Sebaliknya komponen ragam sumbangan pengaruh aditif (D) memiliki harga yang jauh lebih besar dibandingkan komponen ragam sumbangan pengaruh dominan $(\mathrm{H})$ ( Tabel 8).

Dari kecilnya pengaruh gen dominan terhadap densitas stomata dan berdasarkan harga komponen ragam sumbangan pengaruh interaksi $\mathrm{F}$ yang negatif tampaknya pengaruh tersebut lebih banyak berasal dari tetua P2 (tetua toleran). Perbandingan antara $h^{2} n s / h^{2} b s$ juga mendukung bahwa keragaman genetik densitas stomata lebih besar disebabkan oleh sumbangan keragaman aditif.

Nilai heritabilitas arti luas $\left(\mathrm{h}^{2} \mathrm{bs}\right)$ untuk densitas stomata sekitar $72 \%$ dan nilai heritabilitas arti sempit $\left(\mathrm{h}^{2} \mathrm{~ns}\right)$ sekitar 59\% (Tabel 9). Nilai duga heritabilitas menunjukkan bahwa peubah densitas stomata terutama dikendalikan oleh faktor genetik dan proporsi varians aditif memberikan sumbangan yang cukup tinggi. Varians aditif yang ada juga dapat difiksasi melalui seleksi sehingga seleksi dengan menggunakan peubah ini dapat dilakukan pada tahap-tahap awal generasi.

Laju kehilangan air daun (RWL). Pada sebaran frekuensi RWL kedua tetua, meskipun terdapat perbedaan rata-rata yang sangat nyata tetapi juga terlihat sedikit tumpang tindih (uji t Tabel 2). Tetua peka cenderung memiliki RWL yang jauh lebih besar dibandingkan tetua toleran.
Sebaran dan rata-rata F1 cenderung lebih kecil dibandingkan tetua toleran meskipun ada sebagian yang memiliki harga yang mirip dengan tetua toleran. Sebaran dan rata-rata BC1P1 dan BC1P2 cenderung membentuk sebaran di antara tetua peka (cv. Kelinci) dan tetua toleran (US-605). Berdasarkan

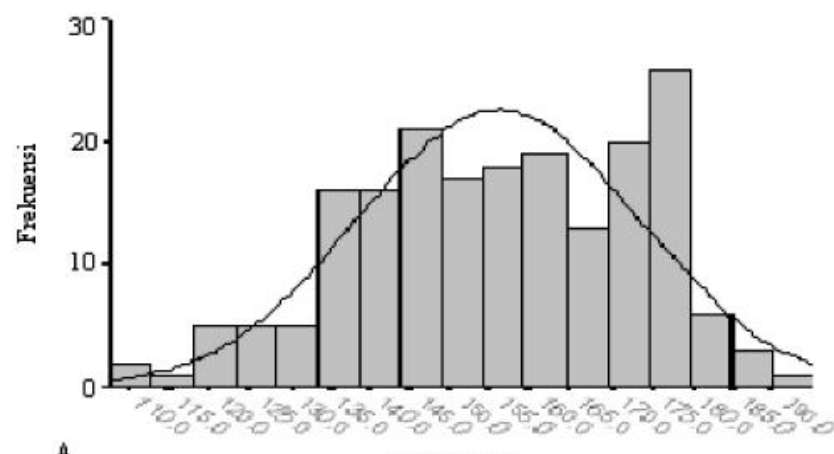

STOMATA

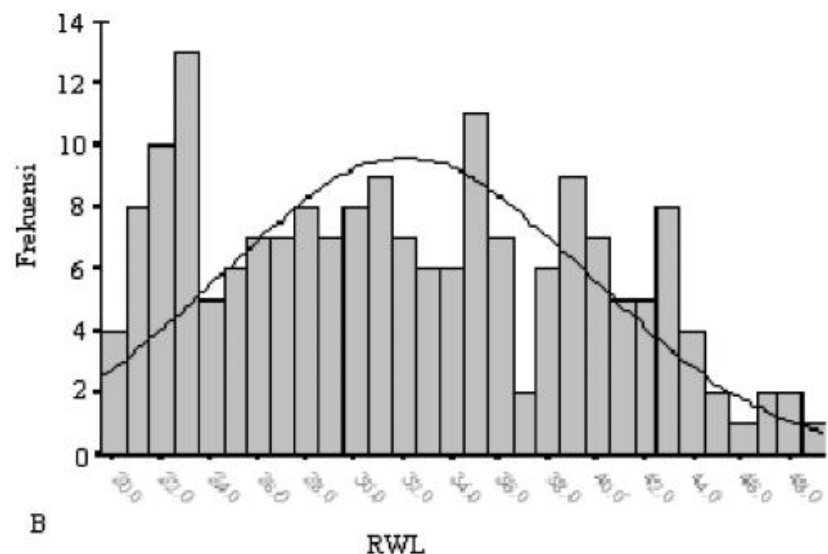

Gambar 2 Sebaran data densitas stomata dan laju kehilangan air daun kacang tanah pada populasi F2 hasil persilangan cv. Kelinci dan US 605

Tabel 6 Nilai $\mathrm{X}^{2}$ uji kebaikan suai peubah densitas stomata dan rate leaf water loss (laju kehilangan air daun RWL) sebagai karakter toleran cekaman kekeringan yang dihasilkan kacang tanah hasil persilangan cv. Kelinci x US-605 pada kondisi tercekam kekeringan

\begin{tabular}{|c|c|c|c|c|c|c|c|c|}
\hline Peubah & $\mathrm{m}[\mathrm{d}]$ & $\mathrm{m}[\mathrm{d}][\mathrm{h}]$ & $\mathrm{m}[\mathrm{d}][\mathrm{h}][\mathrm{i}]$ & $\mathrm{m}[\mathrm{d}][\mathrm{h}][\mathrm{j}]$ & $\begin{array}{l}\text { Model gen } \\
\mathrm{m}[\mathrm{d}][\mathrm{h}][1]\end{array}$ & $\mathrm{m}[\mathrm{d}][\mathrm{h}][\mathrm{i}][\mathrm{j}]$ & $\mathrm{m}[\mathrm{d}][\mathrm{h}][\mathrm{i}][\mathrm{l}]$ & $\mathrm{m}[\mathrm{d}][\mathrm{h}] \mathrm{j}][\mathrm{l}]$ \\
\hline Densitas stomata & 5,601 & 5,572 & 2,394 & 5,567 & 4,328 & 2,280 & $0,058 \mathrm{~ns}$ & 4,180 \\
\hline RWL & 147,193 & 51,992 & 41,891 & 32,021 & 23,479 & 25,412 & 1,550 & 14,589 \\
\hline
\end{tabular}

Tabel 7 Komponen genetik dari model genetik yang sesuai untuk densitas stomata daun kacang tanah hasil persilangan Kelinci $\mathrm{x}$ US-605 pada kondisi tercekam kekeringan

\begin{tabular}{cccccc}
\hline \multirow{2}{*}{ Karakter } & Model genetik & \multicolumn{3}{c}{ Komponen genetik + galat baku } \\
\cline { 3 - 6 } & yang sesuai & $\mathrm{m}$ & $\mathrm{d}$ & $\mathrm{h}$ & $\mathrm{i}$ \\
\hline Densitas stomata & $\mathrm{m}[\mathrm{d}][\mathrm{h}][\mathrm{i}][1]$ & $137,08 \pm 10,22 * *$ & $12,05 \pm 2,10 * *$ & $48,87 \pm 28,70 \mathrm{~ns}$ & $20,96 \pm 10,14 \mathrm{~ns}$ \\
\hline
\end{tabular}

Tabel 8 Pendugaan komponen ragam serta parameter genetik peubah densitas stomata dan rate leaf water loss (laju kehilangan air daun RWL) sebagai karakter toleran cekaman kekeringan yang dihasilkan kacang tanah hasil persilangan Kelinci $\mathrm{x}$ US-605 pada kondisi tercekam kekeringan

\begin{tabular}{lcrrr}
\hline & & Komponen ragam & H & F \\
\hline Karakter & E & D & $-197,26$ & $-140,84$ \\
Densitas Stomata & 66,87 & 544,07 & $-119,35$ \\
Laju Kehilangan Air Daun & 29,48 & 116,13 & $-52,48$ \\
\hline
\end{tabular}

Tabel 9 Nilai duga heritabilitas arti luas ( $\left.h^{2} \mathrm{bs}\right)$ dan heritabilitas arti sempit $\left(\mathrm{h}^{2} \mathrm{~ns}\right)$ serta estimasi jumlah gen pengendali karakter densitas stomata dan laju kehilangan air dari daun (RWL) pada populasi kacang tanah hasil persilangan cv. Kelinci dan US 605

\begin{tabular}{|c|c|c|c|}
\hline Karakter & $\mathrm{h}^{2} \mathrm{bs}$ & $\mathrm{h}^{2} \mathrm{~ns}$ & Estimasi jumlah gen \\
\hline Densitas stomata & 0,7163 & 0,5935 & 0,3099 \\
\hline Laju kehilangan air daun (RWL) & 0,4164 & 0,5031 & 0,6013 \\
\hline
\end{tabular}


uji normalitas Shapiro Wilk pada generasi F2 diketahui sebaran data RWL tidak normal (Gambar 2) dan terletak di antara rata-rata RWL kedua tetua. Oleh karena itu telaah aksi gen untuk RWL juga dilakukan dengan pendekatan genetika Mendel.

Pada perbandingan dua kelas ada 7 kelas perbandingan yang memiliki nilai $\mathrm{x}^{2}$ hitung lebih kecil dari $\mathrm{x}^{2}$ tabel dan pada pengelompokkan tiga kelas ada 3 kelas perbandingan yang memiliki nilai $\mathrm{x}^{2}$ hitung lebih kecil dari $\mathrm{x}^{2}$ tabel (Tabel 6). Dari semua hasil uji tersebut nisbah fenotipik (101 toleran banding 81 peka) yang paling sesuai dengan nisbah harapan 108,56 toleran banding 84,44 peka atau nisbah 9:7 $\left(x^{2}=0,7824\right)$. Dengan demikian RWL dikendalikan oleh 2 pasang gen duplikat resesif epistasis, aa epistasis terhadap B dan b; bb epistasis terhadap A dan a.

Sebaran data yang diperoleh merupakan suatu sebaran terusan memberi indikasi bahwa RWLjuga dikendalikan oleh gen-gen minor. Untuk itu dilakukan analisis rata-rata generasi dengan Uji Skala Gabungan. Berdasarkan nilai c ${ }^{2}$ uji kebaikan suai diketahui bahwa tidak ada model yang sesuai untuk model genetik RWL (Tabel 8).

Berdasarkan nilai derajat dominansi yang $<-1(-2,35)$ terjadi gejala overdominan pada peubah RWL (Tabel 1). Namun demikian dari analisis komponen ragam sumbangan pengaruh aditif (D) memiliki harga yang jauh lebih besar dibandingkan komponen ragam sumbangan pengaruh dominan $(\mathrm{H})$. Berdasarkan harga komponen ragam sumbangan pengaruh interaksi $\mathrm{F}$ yang negatif, pengaruh dominan tampaknya berasal dari tetua P2 (tetua toleran).

Nilai heritabilitas arti luas ( $\left.\mathrm{h}^{2} \mathrm{bs}\right)$ untuk RWL sekitar $42 \%$ dan nilai heritabilitas arti sempit $\left(\mathrm{h}^{2} \mathrm{~ns}\right)$ sekitar $50 \%$ (Tabel 9). Dengan nilai duga heritabilitas yang demikian menunjukkan bahwa peubah RWL terutama dikendalikan oleh faktor genetik dan proporsi varians aditif memberikan sumbangan yang cukup tinggi. Varians aditif yang ada juga dapat difiksasi melalui seleksi sehingga seleksi dengan menggunakan peubah ini dapat dilakukan pada tahap-tahap awal generasi.

\section{SIMPULAN}

Berdasarkan hasil analisis diketahui bahwa densitas stomata dan laju kehilangan air daun selain dikendalikan karakter kualitatif oleh gen-gen mayor, juga dikendalikan oleh karakter kuantitatif yang dikendalikan oleh gen-gen minor secara poligenik dengan aksi gen yang kompleks. Tidak hanya ditentukan oleh pengaruh aditif dan dominan tetapi juga oleh pengaruh interaksi antar gen. Kedua karakter tampaknya lebih dipengaruhi oleh faktor genetik dan memiliki tingkat kemudahan fiksasi varians aditif yang tinggi sehingga peluang untuk memperoleh generasi yang toleran berdasarkan kedua peubah mudah dilakukan pada tahapantahapan awal generasi.

\section{UCAPANTERIMAKASIH}

Terimakasih disampaikan kepada Dr. Sudarsono atas fasilitas laboratorium Biologi Molekular Tanaman untuk penelitian ini dan Dr. Kukuh Setiawan atas sumbangan serta izin penggunaan koleksi genotipe kacang tanahnya. Terimakasih juga disampaikan kepada pihak Balitbio/BB Biogen Kementrian Pertanian yang telah mengizinkan penggunaan fasilitas green-house selama penelitian ini.

\section{DAFTAR PUSTAKA}

Aspinwall, M.J., King, J.S., Domec, J.C., McKeand, S.E. \& Isik, F. 2011. Genetic effects on transpiration, canopy conductance, stomatal sensitivity to vapour pressure deficit and cavitation resistance in Loblolly pine. Ecohydro l 4: 168182 .

Carmo-Silva, A.E., Francisco, A., Powers, S.J., Keys, A.J., Ascensao, L., Parry, M.A.J. \& Arrabaca, M.C. 2009. Grasses of different $\mathrm{C}_{4}$ subtype reveal leaf traits related to drought tolerance in their natural habitats: Changes in structure, water potential, and amino acid content. American Journal of Botany 96(7): 1222-1235.

Chaves, M.M., Maroco, J.P. \& Pereira, J.S. 2003. Understanding plant responses to drought - From genes to the whole plant. Functional Plant Biology 30: 239-264.

Crowder, L.V. 1993. Genetika tumbuhan. Diterjemahkan oleh L. Kusdiarti. Gadjah Mada Univ. Press.

Das, M.K. \& Griffey, C.A. 1994. Heritability and number of genes governing adult plant resistance to powdery mildew in Houser and Redcoat winter wheats. Phytopathology 84: 406-409.

Domec, J-C., Noorments, A., King, J.S., Sun, G., McNulty, S.G., Gavazzi, M.J., Boggs, J.L. \& Treasure, E.A. 2009. Decoupling the influence of leaf and root hydraulic conductances on stomatal conductance and its sensitivity to vapour pressure deficit as a soil dries in a drained Loblolly pine plantation. Plant Cell and Environment 32: 980-991.

Ennajeh, M., Vadel, A.M., Cochard, H. \& Khemira, H. 2010. Comparative impacts of water stress on the leaf anatomy of a drought-resistant and drought-sensitive Olive culture. Journal of Horticultural Science \& Biotechnology 85(4): 289-294.

Fehr, W.R. 1987. Principle of cultivar development. Theory and technique. Vol I MacMillan Pub. Co. New York.

Kholova, J., Hash, C.T., Kakkera, A., Kocova, M. \& Vadez, V. 2010. Constitutive water-conserving mechanisms are correlated with the terminal drought tolerance of Pearl Millet [Punnisetum glaucoma (L.) R. Br.]. Journal of Experimental Botany 61(2): 369-377.

Lande, R. 1981. The minimum number of genes contributing to quantitative variation between and wiyhin population. Genetics, 99: 541-553.

Mather, K. \& Jink, J.L. 1982. Biometrical Genetics: The Study of Continous Variations. $3^{\text {rd }}$ Ed. Chapman and Hall.

Nigam, S.N., Chandra, S., Rupa Sridevi, K., Manohar Bhukta \& Reddy, A.G.S. 2005. Efficiency of physiological trait-Based and empirical selection approaches for drought tolerance in Groundnut. Ann. Applied Biol 146: 433-493.

Painawadee, M., Jogloy, S., Kesmala, T., Akkasaeng, C. \& Patanothai, A. 2009. Heritability and correlation of drought resisteance traits and agronomic traits in Peanut (Arachis hypogaea L.). 
Petr, F.C. \& Frey, K.J. 1966. Genotypic correlation, dominance, and heritability of quantitative characters in oats. Crop Sci 6: 259-262.

Pimratch, S., Jogloy, S., Vorasoot, N., Toomsan, B., Patanothai, A. \& Holbrook, C.C. 2008. Relationship between biomass production and nitrogen fixation under drought stress conditions in Peanut genotypes with different levels of drought resistance. J. Agron. Crop. Sci 194: 15-25.

Rauf, S. \& Sadaqat, H.A. 2008. Identification of physiological traits and genotypes combined to high achene yield in Sun flowe (Helianthus annus L.) under contrasting water regimes. Aus. J. Crop Sci 1: 23-30.

Simon, M.R. 1994. Gene action and heritability for photosynthetic activity in two wheat crosses. Euphytica 76: 235-238.

Solangi, A.H., Arain, M.A. \& Iqbal, M.Z. 2010. Stomatal studies of Coconut (Cocos nucifera L.) varieties at coastal area of Pakistan. Pak. J. Bot 42(5): 3015-3027.

Songsri, P., Jogloy, S., Vorasoot, N., Akkasaeng, C., Patanothai, A. \& Holbrook, C.C. 2008. Root distribution of drought resistance peanut genotypes in response to drought. J. Agron. Crop Sci 194: 92-103.

Tawfik, K.M. 2008. Effect water stress in addition to potassiomag application on Mugbean. Aus. J. Basic \& Appl. Sci 2(1): 42-52.

Xiang, L., Wang, R-G., Mao, G. \& Koczan, J.M. 2006. Identification of drought tolerance determinant by genetic analysis of root response to drought stress and abscisic acid. Plant Physiol 142: $1065-1074$

Yang, R.C., Jana, S. \& Clarke, J.M. 1991. Phenotypic diversity and association of some potentially drought responsive characters in durum wheat. Crop Sci 31: 1484-1491. 